\title{
Genesis of Shamanic Instruments in the Light of the Yakuts' and Mongols' Mother-Beast Image
}

\author{
Valerii E. Vasilev* \\ Institute for Humanities Research \\ and Indigenous Studies of the North SB RAS \\ 1 Petrovskogo Str., Yakutsk, Russia, \\ Sakha Republic (Yakutia), 677027, Yakutsk
}

All the peoples of a vast northern part of Eurasia and the Arctic, in particular, have known the idea of sacredness of the feminine origin of mother-goddesses, giving birth to all life on earth, since the Paleolithic and Neolithic ages. It is probably that time that Siberian shamanism originates from. It is based on the animistic ideas on the cycle of souls of fur-bearing animals, birds and revered people who were buried the same way inside damp caves. This can be clearly seen in the bear feast, the genesis of which is observed in Eurasian ancient monuments. In their ethnographic past the peoples of Siberia had the custom of the totem birds', beasts' and shamans' bones burial on the tree branches or in the tree hollows. More developed animism forms led to the construction of sarcophagi and air burials on poles. The fetishes, associated with totemism and the cult of ancestors, have been widely used in Siberian shamanism until recently. Sometimes they are found in their relic and transformed form in the ceremonies of modern holidays as well as in urban "shamans"” and psychics' practice. However, the fact that remains unchanged is that tambourines and stringed instruments have always been one of the most important attributes, the instruments prototypically running back to hunting bows and bags for storage of their ancestors' spirits. In a more rigorous understanding of this phenomenon the fetishes in archaic societies served as ancestral shrines and turned into musical instruments much later.

Keywords: shamanism, totemism, the mother-beast cult, commercial hunting, fertility, shamanic attributes, bow, tambourine, kobyz.

DOI: 10.17516/1997-1370-2016-9-10-2531-2537.

Research area: ethnography, ethnology and anthropology.

Long-term researches of shamanism have lead the ethnographers to a vital conclusion that all early forms of Siberian ethnic groups' religion must be considered in their organic integrity as every single cult looks disadvantaged and does not reveal the fullness of the ancient people's sacred world if regarded in isolation from the related cults. Only a comprehensive approach to religious thinking of the aborigines of Siberia and the Arctic will make it possible to retract the scientific methodology, trying to show shamanism as the mentality of ethnic groups remaining at the

(C) Siberian Federal University. All rights reserved

* Corresponding author E-mail address: valera305@mail.ru 
level of their "ahistoric" development and being unable to create their own national ideology. An imperial attitude to the spiritual heritage of Siberian aborigines, who have been imposed the values of the world globalization processes having an adverse effect on the ecology of the North and the Arctic, comes partly into view here, the ecology being the basis of the indigenous ethnic groups' vital activity.

A fundamental difference between the two systems is that greed and gains were totally alien to the aborigines' way of thinking, and it was the land inhabited by their ancestors' spirits, through which they perceived the forms of fetishism, totemism and shamanism together, that served the basis of aboriginal true religious feelings. The ancestors' shadows influenced future generations with memorable items that reminded of their lives (bows, quivers, jars, lassos, and other objects) and were endowed with special qualities for contacts with other worlds. Having travelled a difficult way of development, such evolution of shamans' attributes reflected the model of the Universe, and the fetishes served as temporary abodes of spirits and deities and embodied their sacred images at the same time.

The legend of Ellei, the founder of Sakha who put his blind father into a xaahax bag, attached it to the saddle and fled to the North, is a prominent example of the ancestors' cult, rising to shamanism. Different versions of the legend say that an old shaman was 270-300 years, whereas, according to the custom, all elderly people after 70 took a voluntary death. Hence, the conclusion that the legend was not about a living shaman, but about the spirit personifying nine generations of tribal ancestors seems logical. It is curious that the great shamans' tombs had to be updated thrice in the course of 300 years and only then their souls were relegated to oblivion forever. The fact that Ellei was considered the first "white" shaman provides a new meaning for his road saddlebag with the ancestor's bones left on the Verkhniaia Lena (the Upper Lena) and gives us reason to consider it a shaman's tambourine prototype (Vasiliev 1998).

Extending this thesis, we referred to the language of the Buryat Mongols. The lexis of this language demonstrates close parallels with the Yakut xaahax ('bag') and кэhэx ('quiver'), the parallels being $х э) \ni$ and $x \ni и$ ('tambourine') (Bol'shoi akademicheskii mongol'sko-russkii slovar' 2002, further referred to as BAMRS). A quiver as a symbol of the archer warriors was apparently among shamanic attributes. Connection of a quiver to a tambourine is not accidental, as the charms of the bow and the arrow were found in the Mongolian and Turkic shamans' costumes. In the light of this it is worth while drawing attention to folk healer A.K. Chirkova's memory about her father Konstantin Ivanovich, a strong shaman: as a child he often disappeared and played with the local spirits' children (Il'iakhov 1993). The author of the book added an interesting story to it. The story ran that a future shaman would seclude himself in a deserted house (өmөx) and secretly studied the ways of performing shamanistic rituals, using a tambourine instead of a miniature bow and arrow.

Thus, there appears a version about the relationship of a tambourine's body with a kiris string that later turned into the string of a violin. This is evidenced by one fact mentioned by R.K. Maak: "All Yakuts assured me that shamans had not the only instrument they called tungur which they beat with a tampon (bylaiakh) and by means of which they descended to the underworld. They also had another instrument, the instrument being a dugur. Yakut fairy tales say that the shaman beat this dugur with a metal spatula, at the same time runing his fingers over the stretched strings". The researcher explained in the notes that the Mongolian shamans used 
a tambourine as a combat bow and struck their enemies with it (Maak 1994).

R.K. Maak had never seen a tambourine with strings and referred to the "tales" (epos) in which "black" shamans of the lower world could retrieve the sounds by means of metal rods and strings. This leads to vague considerations that a tambourine might have been iron and resembled a bowler. Rather, he meant a forgotten instrument, the prototype of the kyryympa violin with strings of horse hair. Although, in the epic tradition Er Ellei, a lonely hermit, made a primitive bow with a string from the willow bark. He also invented a shatyor (a marquee) and all birch-bark dishes for koumiss holidays. This information was collected by G.F. Miller, who provided his records with a note that shamans kept the myths about Ellei and ordinary people, who knew about these myths, were only those who were told about them by shamans (Elert 1999). This note, which is not included in "The History of Siberia", makes it clear that the myth on Er Sogotokh, a first-born ancestor, told about the origin of shamanism. A willow bow can be schematically associated with a defective ("halved") tambourine divided into two parts by the transverse stringers running from the byaryk arm grip (cf. Yakut 'rope').

The Turkic peoples call the stringed instruments, similar to the violin, kobyz, komus. This shows that their body is hollow. The following etymological parallels prove this: the Yakut hobo 'a hollow jingle'; Buryat haba ('the shaman's magic power'); the ancient Turkic kova ('a bucket, pail'), kovy ('hollow') (Drevnetiurkskii slovar' 1969; further referred to as DTS); the Turkish, Turkic koba ('a cave, hollow, hole'); the Turkic, Tuvinian kova / huva ('a bucket, jug, glass'), the Kalmyk hova ('a leather bag for drawing water') (Etimologicheskii slovar' tiurkskikh iazykov... 2000, further referred to as ESTIa], the Mongolian hobusun ('a well bucket'). From the same root come the Mongolian terms hovd ('a box for arrow storage'), hovs ('a two-year-old boar, hog'); ilbehovs ('hypnosis') (BAMRS). The Mongolian word hovs, corresponding to the Yakut hobusun ('magic'), implies that during their ecstasy the khagans and shamans could be incarnated into young wild boars. The idea of empty cavity is traced in the Kazakh oba ('a mound'), Mongolian ovoo ('a shelter from a pile of stones and willow branches'). A mound and its model ovoo give a clear hint that kobys was originally connected with raw land and the ancestors' grave.

In September 2014 the author of these lines visited the State Historical Museum in Ulan Bator and saw a musical instrument there that was found during the excavations in Altai. In the abstract of the exhibit it is written that Turkic runes, carved along the fingerboard and on the body of a iiailyg stringed instrument, say that it belonged to Chura-warrior who was popular under the name of "Iаiа огul". The violin's oval body was carved from a solid piece of birch, whereas a curved fingerboard made of willow was decorated with a head of a horse with a sharp face. The whole composition reminds of a sailing boat or a flying swan bird. The Mongols call an instrument, similar to kobyz, a morin huur 'a huur horse'. According to the legend of the Turk Oghuz, the first kobyz was created by Korkut-ata shaman, who was born by a mare in a placenta shell. The birth of kama Korkut from a horse's womb suggests that hollow instruments were associated with Umai, a mother-goddess who had the traits of a totem animal.

It can be shown in the scene carved on the back side of a huur: a hunter with five dogs is chasing five wild deer. This is, apparently, a reflection of five months of spring and summer, which were nominated with the names of male fur-bearing animals (roe deer, deer, Siberian stag, mountain sheep and goat) by the Tien Shan Kyrgyz. The next five months of fall and winter were nominated with numeric names: toguzdun 
aiy (the $9^{\text {th }}$ months); zhetinin aiy (the $7^{\text {th }}$ month); beshtn aiy (the $5^{\text {th }}$ month); Ychtyn aiy (the $3^{\text {rd }}$ month); birdin aiy (the $1^{\text {st }}$ month). These months, decreasing on odd days, emphasized a ritual significance of the lunar calendar (Baibosunov 2009). The Kazakh of Mongolia have the remains of the hunters' ancient calendar with a countdown of the autumn-winter months (Mongol-Kazakh tol' 1984).

In an earlier era a huur instrument could incarnate a female deer from whose womb a shamanic spirit appeared. According to the Altaians' beliefs, Siberian stags, woodpeckers and elks were rideable stallions of a taiga or mountain owner (Potapov 2001). In this respect, an illustration of the sixth deer on the bottom of a huur, that was painted later than all the rest characters, is of some interest. It was obviously a totemic ancestor who took the soul of Chur the singer. In other words, the Turks' totems were associated with the mountain game hunting. This interpretation is consistent with the religious scholars' opinion that among sacred beings these are real and useful animals that the peoples of Siberia focus on more often than they do on mythical, harmful and inedible ones (Bereznitsky 2012).

In our opinion, the etymology of the huur term dates back to ancient Turkic ky5yrsak ('stomach') (DTS) and is also associated with the Yakut kuorchakh ('a coffin-deck'). The root of the word is preserved in the Mongolian хөөхур and Yakut көБуөр ('a leather bag for storing koumiss'). A leather-basis of these furs suggests a connection with the female fertility cult. In this regard, we refer to the Buryat folklore, in which the deities of childbirth were presented as bisexual beings, and their female body was compared with a large bag (Dampilova 2012). This information brings us back to the Sakha myth about Ellei and his blind father, sitting inside the xaahax road bag.
The scholars derive the following terms from the root base ko5 $>k o v>k u v>k o b$ ('hollow, empty'): Azerbaijani kо5иsh, Turkish dialect kavush, Uzbek dialect kovash, Tatar kuvysh, Tatar dialect ku5ys, Bashkir kyvysh, Chuvash haval mean 'a cavity', 'a support beam, ceiling tie-beam' (ESTIa). The Turkic words ko5ush, kuђys are related to the Yakut көБYс ('back, the trunk of the body') and rhotacism көБYөр ('a bag for storing koumiss'). Taking into account that the middle phoneme 5 drops in the Yakut word $\kappa \theta 5 Y c$, then the form $\kappa Y \theta c$ ('a clay pot') is derived. If desired, koumiss can also be added, koumiss being a drink of gods, leading to the people's light intoxication comparable to ecstasy. This idea is reinforced by the fact that a filled with food boiler symbolizes grace, wealth and happiness in rituals.

The iaialyg violin is worth giving special consideration. The plate under the museum exhibit runs that khuur was called iaialyg by the ancient Turks. T. Battulga, a Mongolian professor, compares this word with the Mongolian aialguut ('melody') and is of the opinion that the name of Iiaia o5ul should be read as 'the Son of melody'. This hypothesis is questioned. It is obvious that the addition of the suffix -lyg to the iaia root must form the concept of 'an instrument with iaia'. But what does the iaia word mean then? Basing on the fact that kobyz and huur were shamanistic attributes, we can assume that the ancient Turkic word iaia is an " $a$ pronouncing" analogue to the modern ieie, iiie, iie, iiae, iia, ie, esh, iche, ichchi terms with a common meaning 'owner, master', 'spirit' (Sevortian 1974). In this case, iaialyg is translated as 'a (tool) with a master-spirit'. We tend to compare the proper name Iiaia o5ul with the Yakut Aiyy iola ('the son of the Creator'). The first part of the name iiaia is present in the Altai term iaiaachy ('a creator'). Generally, Chur the singer, lying in a mound, should be considered a revered man - a shaman of the warlike Teles tribes. 
Thus, vessels made of skin, clay, bark and tree, the cavities of which are associated with the mother-goddesses' wombs, could serve ancient prototypes of shamanic tools. The Turks' and Mongols' shamans interacted with the spirits of other worlds with their help, thus providing good fortune in commercial hunting and cattle breeding. The same idea of a mother goddess's womb in the form of a sacred vessel had to be the base of tambourines of the Tungus ethnic groups of the Far North. Their shamanism dates back to Altai common layer of cultural genesis, widespread from Eastern Siberia to Korea and Japan, which generates new hypotheses for the research.

The following preliminary findings can be made public against this background:

The cult of aiyy creators is inseparable from a system of the Sakha people's shamanism, whereas "white" shamans were priests of those clans and tribes that kept horses. At that the light-patrons of horse cattle were equal to the totem deity-spirits and shaman-ancestors. Very archaic beliefs associated with the cults of the earth and foremothers were in the basis of the cult of the Aiyyhyt mother-goddesses. In later eras the earth goddesses were displaced by male deities. As wives or daughters of the heavenly creators they dubbed their names and functions. Shamanic tambourines, drums and violins were symbols of the totemic ancestors' wombs; their sacred trees grew over the shamans' graves. Coffin blocks, leather bags and funeral urns, which served as containers for storing the souls of the ancestors for whom reincarnation to continue the shamanic kind was inherent to, were early prototypes of ritual instruments.

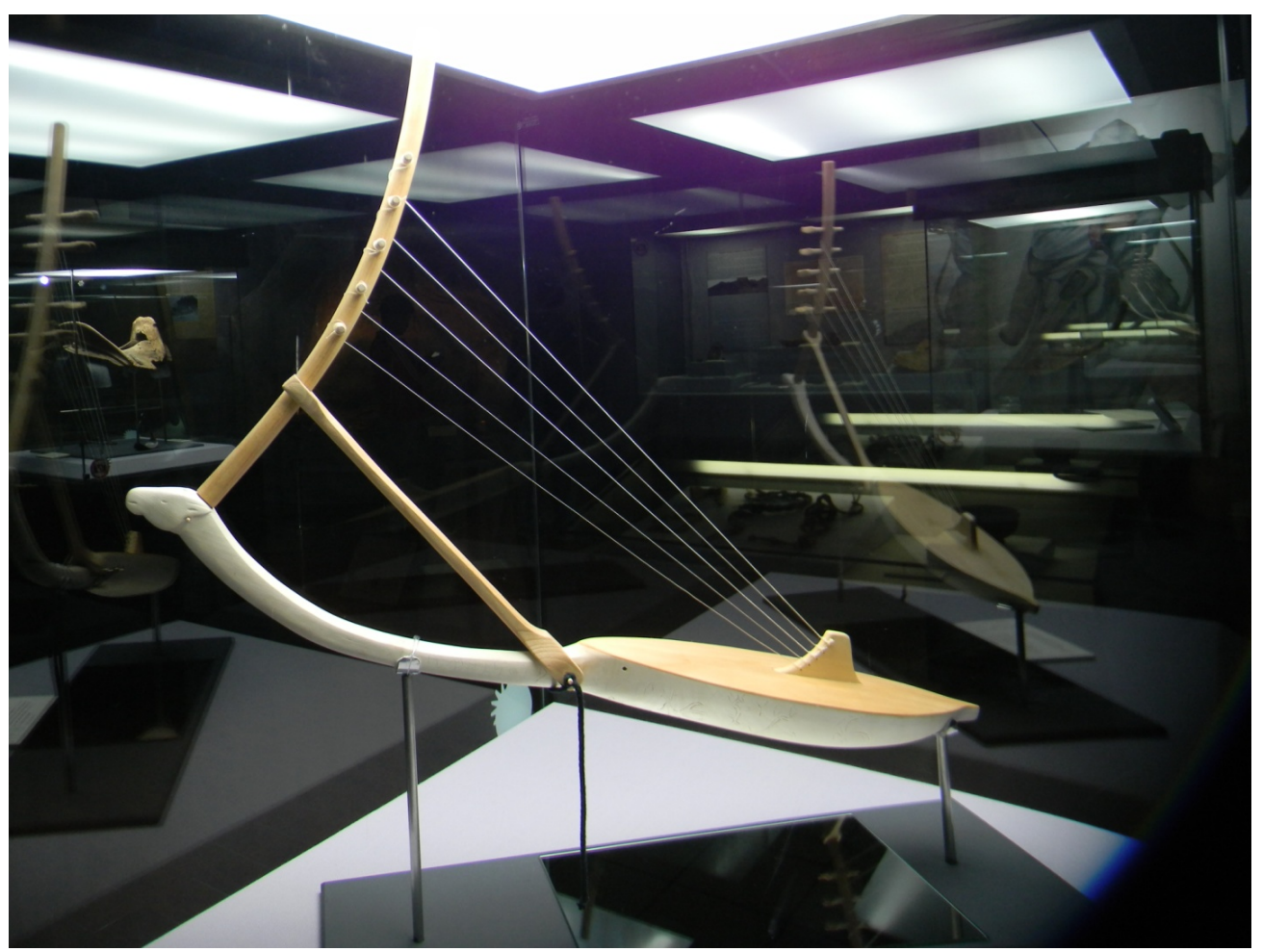

Restoration of the iaialyg music instrument owned by Chura, a Turk popularly known as Iaia o5ul. The National Museum of Mongolia, Ulan Bator. Photo by the author. 2014 


\section{References}

Baibosunov, A.A. (2009). Donauchnye predstavleniia kirgizov o prirode i obshchestve [The Kyrgyz People' Pre-Scientific Views on Nature and Society]. Bishkek, Akyl, 312 p.

BAMRS (2002) - Bol'shoi akademicheskii mongol'sko-reuuskii slovar'. T. 4. Kh - Ia [The Large Academic Mongolian-Russian Dictionary. Vol. 4. Kh - Ia]. Ed. G.Ts. Prbeev. Moscow, Academia, $5532 \mathrm{p}$.

Bereznitskii, S.V. (2012). Kriterii otbora zhivotnykh v kategoriiu pochitaemykh (po materialam verovanii i ritualov korennykh narodov Severa) [Criteria for Selection of Animals into the Category of the Revered (according to the Beliefs and Rituals of the Indigenous Peoples of the North)], In Trudy Gosudarstvennogo Muzeia Istorii Religii [Proceedings of the State Museum of History of Religion], $12,115-122$.

Dampilova, L.S. (2012). Shamanskie pesnopeniia buriat: simvolika i poetika [The Buryarts' Shamanic Chants drilled: Symbolism and Poetics]. Moscow, Vostochnaia literatura, 263 p.

DTS (1969) - Drevnetiurkskii slovar' [Ancient Turkic Dictionary]. Leningrad, Nauka (Leningradskoe otdelenie), $676 \mathrm{p}$.

Elert, A.Kh. (1999). Narody sibiri v trudakh G.F. Millera [The Peoples of Siberia in G.F. Miller's Works]. Novosibirsk, Publishing House of the Institute of Archeology and Ethnography of the Siberian Branch of the Russian Academy of Science, $240 \mathrm{p}$.

ESTIa (2000) - Etimologicheskii slovar' tiurkskikh iazykov: Obshchetiurkskie i mezhtiurkskie leksicheskie osnovy na bukvu "K" [Etymological Dictionary of Turkic Languages: General Turkic and Inter-Turkic Lexical Basics with the Letter "K”]. Moscow, Indrik, 265 p.

Il'iakhov, P.N. (1993). Uluu oiiuun olo5utan (Iz zhizni velikogo shaman) [Uluu oiiuun olo5utan (From the Great Shaman's Life)]. Yakutsk, Bichik, 80 p.

Maak, R.K. (1994). Viliuiskii okrug [Vilyui District]. Moscow, Iana, 592 p.

Mongol-Kazakh tol' [Mongol-Kazakh Roofing Felt] (1984) / Comp. B. Bazylkhan. Ulaanbaatar, Olgii; IIaiL AN MNR, 887 p.

Sevortian, E.V. (1974). Etimologicheskii slovar' tiukrskikh iazykov: (Obshchetiurkskie i mezhtiurkskie osnovy na glasnye) [Etymological Dictionary of the Turkic Languages: (General Turkic and Inter-Turkic Bases on Vowels)]. Moscow, Nauka, 767 p.

Vasil'ev, V.E. (1998). Kul't shamanov i istoki prazdnikov ysyakh [The Cult of Shamans and the Origin of the Ysyakh holidays]. G.V. Ksenofontov: Vozvrashchenie k sebe: Sbornik nauchnykh statei [G.V. Ksenofontov: Return to Oneself: Collection of Articles]. Yakutsk: IGI AN PS (Ia), 46-56. 


\title{
Генезис шаманских инструментов \\ в свете образа матери-зверя \\ у якутов и монголов
}

\author{
В.Е. Васильев \\ Институт гуманитарных исследований \\ и проблем малочисленных народов Севера СО РАН \\ Россия, 677027, Якутск, \\ Республика Саха (Якутия), ул. Петровского, 1
}

\begin{abstract}
У всех народов широкой северной полосы Евразии и, в частности, Арктики идея сакральности женского начала богинь-матерей, порождающих всё живое на Земле, была известна с эпохи палеолита и неолита. Вероятно, именно с той поры берёт начало и сибирское шаманство, в основе которого лежали анимистические представления о круговороте душ промысловых зверей, птиц и почитаемых людей, схожим образом хоронимых внутри сырых пещзер, что отчётливо видно в медвежьем празднике, генезис которого наблюдается в древнейших памятниках Евразии. В этнографическом прошлом у народов Сибири существовал обычай погребения костей тотемных птии, зверей и шаманов на ветвях или в дуплах растущчи деревьев. Более развитые формы анимизма привели к сооружению саркофагов и воздушных погребений на столбах. В сибирском шаманстве фетиши, связанные с тотемизмом и культом предков, иироко применялись до недавних пор. Иногда они в пережиточной, трансформированной форме встречаются в церемониях современных праздников, а также в практике разных городских «шаманов» и экстрасенсов. Но неизменныл остаётся то, что одним из самых важных атрибутов всегда выступают бубны и смычковые или струнные инструменты, восходящие к прототипам как охотничьи луки и мешки для хранения духов предков. В более строгом понимании данного феномена эти фетиши в архаических обществах служили родовыми святынями и лишь гораздо позднее превратились в музыкальные инструменты.
\end{abstract}

Ключевые слова: иаманизм, тотемизм, культ матери-зверя, промысловая охота, плодородие, иаманские атрибуты, лук, бубен, кобыз.

Научная специальность: 07.00.07 - этнография, этнология и антропология. 